\title{
MENGENALKAN LAMBANG BILANGAN MELALUI PERMAINAN MENJATUHKAN SIMBOL ANGKA PADA ANAK USIA DINI
}

\author{
Achmadi \\ PG - PAUD Universitas PGRI ADI BUANA Surabaya \\ achmadi@unipasby.ac.id
}

\begin{abstract}
Most early childhood have dificulties for learning numerical. For example, When they are studing, they are tied, boring, and unresponsible about numerical stimulus. So that way they did not have capabilities to respon about numerical. The child has capabilities to say number one to ten only, but he does not understand about the number. One of the problems is coused by the teacher and the child hiself. The teacher's problem is the inappropriate of instruction learning, so the result of learning is not good enought. While the children's problems are coused by less of motivated, and less of learning media that is not increase to student's motivation. Based on these problems, so the researcher wants to know to increase of numbers capabilities by using of the number game for early childhood. The goals of this reaearch is the falling of symbol number is efective to introduce about number for early childhood. As indicator of efectiveness are: 1). The children can say number corectly and orderedly. 2). The children can ordere the number from small to higher corectley. 3). The children can related among symbol number and the total of material number.4). The children can write the symbol of number corectly. This research is a quasi experiment by one group pretes posttest design. The collecting data uses performance tes and observation. While the analysis data uses $t$ statistical. The result of this research has purpose to introduce of the symbol number throught the game for falling the symbol number.
\end{abstract}

Kata kunci: Game, Falling the Symbol Number

\section{LATAR BELAKANG}

Anak usia dini adalah anak yang berusia 0 sampai dengan 6 tahun. Masa ini merupakan usia yang efektif untuk dikembangkan dari berbagai potensi yang dimilikinya. Proses pengembangan yang efektif bagi anak usia dini salah satunya melalui bermain sebab bermain merupakan dunianya anak usia dini. Anak-anak yang kebutuhan bermainnya terpenuhi akan tumbuh dengan baik dan memiliki keterampilan hidup serta dapat menyesuaikan terhadap lingkungan dengan tepat. Ada berbagai macam jenis permainan. Salah satunya adalah permainan melempar untuk menjatuhkan sesuatu yang dapat digunakan dalam kegiatan pembelajaran mengenal lambang bilangan untuk anak usia dini. Permainan menjatuhkan sesuatu itu merupakan kegiatan yang mengasyikkan anak. Pelaksanaan dalam permainannya dapat dimodifikasi sesuai dengan karakteristik anak. Hal itu dapat dilakukan oleh anak sesuai dengan permintaan orang lain.
Misalnya, Anak disuruh melempar bilangan 5, 7, 9, dst. Anak disuruh menyebutkan angka yang telah dijatuhkan atau dilempar. Anak disuruh mengurutkan angka sesuai dengan angka-angka yang telah dijatuhkan. Bila permintaan itu semua dapat dilakukan anak, berarti anak telah mengenal angka secara matang. Di samping itu, kegiatan ini bisa mengasyikkan anak karena bentuk lemparannya dapat dimodifikasi sesuai dengan kemampuan dan kondisi anak. Misalnya, anak senang dengan melemparkan bola, dengan menggelindingkan bola, dengan menendangkan bola bahkan dengan menjatuhkan bola dari atas sasaran yang dituju. Dalam kegiatan ini, masalah jarak lemparan juga tidak dipermasalahkan, yang penting anak dapat menjatuhkan sesuatu dengan rasa senang hati. Jadi, bentuk permainan menjatuhkan simbol angka merupakan alasan yang dipilih untuk mengenalkan lambang bilangan bagi anak usia dini. Untuk itu, permainan menjatuhkan simbol suatu angka dapat dijadikan wahana anak sambil bermain anak bisa mengenal 
lambang bilangan. Sebab, anak usia dini harus seawal-awalnya diberikan stimulasi terhadap semua aspek perkembangan. Salah satunya menstimulasi pengenalan lambang bilangan. Hal ini sesuai dengan isi kurikulum Taman Kanak-Kanak tentang Pedoman Pengembangan Silabus di Taman KanakKanak, yaitu "Berhitung Permulaan". Adapun target yang ingin dicapai melalui penelitian ini antara lain: a) Anak dapat membilang/mengurutkan konsep bilangan dengan tepat, b) Anak dapat menunjukkan/membedakan kosep bilangan dengan lambang bilangan dengan benar, c) Anak dapat mencocokkan jumlah benda dengan lambang bilangan, d) Anak dapat menuliskan lambang bilangan dengan tepat. Terkait dengan pengenalan bilangan/angka bagi anak usia dini, salah satu upaya untuk meraih tujuan tersebut dapat melalui permain menjatuhkan angka.

\section{METODE PENELITIAN}

Metode penelitian yang digunakan adalah penelitian kuantitatif. Adapun jenis penelitian ini adalah eksperimen semu (quasi eksperimental) bentuknya one group pretest post tes design. Tujuan penelitian ini adalah ingin mengetahui hasil keefektifan permainan menjatuhkan angka untuk mengenalkan lambang bilangan bagi anak kelompok A PAUD Nurul Jadid, Tumapel No. 106 A, Ketajen, Gedangan, Sidoarjo. Sedangkan, rancangan penelitiannya dilakukan dengan menggunakan rancangan berpola: pre tes $\rightarrow \quad$ tindakan (permainan menjatuhkan angka) $\rightarrow$ post tes. Langkah penelitian yang penulis lakukan antara lain (1) merencanakan: perizinan, instrumen penelitian, dan media permainan, serta menentukan guru PAUD sebagai mitra penelitian (2) melaksana kan: Bersama guru, mitra melaksanakan kegiatan pengenalan lambang bilangan 1-10 melalui permainan menjatuhkan lambang bilangan. Melaksanakan pengamatan saat anak bermain dan melakukan post tes. Adapun bentuk post testnya antara lain (a) Anak diminta untuk membilang atau menyebut angka yang telah dijatuhkan, (b) Anak diminta untuk mengurutkan dari bilangan kecil ke besar dari bilangan-bilangan yang telah dijatuhkan, (c) Anak diminta untuk mencocokkan antara jumlah benda dengan lambang bilangannya, (d) Anak diminta untuk menuliskan lambang bilangan yang telah dijatuhkan.

Metode pengumpulan data yang penulis gunakan (1) Tes unjuk kerja yaitu anak harus mempraktikkan apa yang diminta guru. Misalnya, anak diminta untuk menjatuhkan lambang bilangan 6. Anak melaksanakan perintah guru, dengan mencari dan memilih pin yang berlogokan angka 6. Bila anak melakukannya salah, berarti anak tersebut belum mengenal lambang bilangan atau angka 6. Atau anak diminta mengurutkan bilangan yang telah dijatuhkan dari angka kecil menuju ke angka besar, atau sebaliknya dari angka besar menuju ke angka kecil, (2) metode observasi: Dalam artikel ini, digunakan metode observasi nonpartisipatoris, yakni mengamati kegiatan anak saat bermain dan menjalankan perintah atau tugas dari gurunya dalam jarak tertentu. Suatu saat mendekat dengan anak-anak, dan suatu saat menjauh mengikuti aturan main anak. Dua metode tersebut sebagai metode pokok dalam pengumpulan data dalam penelitian ini. Selanjutnya, sesuai dengan tujuan penelitian ini, setelah memperoleh data akan dianalisis dengan menggunakan analisis data dengan statistik Uji T. Analisis ini untuk mendapatkan hasil perhitungan seberapa besar efektivitas pengenalan lambang bilangan melalui permainan menjatuhkan lambang bilangan pada anak kelompok A PAUD Nurul Jadid Ketajen, Gedangan, Sidoarjo.

\section{HASIL PENELITIAN DAN PEMBAHASAN}

\section{Hasil Penelitian}

Sebelum dilaksanakan tindakan penelitian dengan jalan bermain menjatuhkan lambang bilangan, maka kondisi kemampuan membilang dan mengenal konsep bilangan bagi anak PAUD kelompok A masih rendah dan masih bersifat hafalan. Hal ini terbukti dari hasil pre tes dan post tes dalam penelitian ini sebagai berikut. 
Tabel 1. Hasil Nilai Pre Test dan Post Test

\begin{tabular}{|c|c|c|c|c|c|c|c|c|c|c|c|}
\hline \multirow[t]{2}{*}{ No } & \multirow[t]{2}{*}{ Anak } & \multicolumn{4}{|c|}{$\begin{array}{c}\text { Nilai } \\
\text { Tugas Pre } \\
\text { Tes }\end{array}$} & \multirow[t]{2}{*}{$\begin{array}{l}\text { To } \\
\text { tal }\end{array}$} & \multicolumn{4}{|c|}{$\begin{array}{c}\text { Nilai } \\
\text { Tugas Post } \\
\text { Tes }\end{array}$} & \multirow[t]{2}{*}{$\begin{array}{l}\text { To } \\
\text { tal }\end{array}$} \\
\hline & & 1 & 2 & 3 & 4 & & 1 & 2 & 3 & $\overline{4}$ & \\
\hline 1. & AA & 3 & 2 & 3 & 2 & 10 & 4 & 2 & 3 & 3 & 12 \\
\hline 2. & BB & 3 & 2 & 3 & 2 & 10 & 3 & 2 & 3 & 2 & 10 \\
\hline 3. & $\mathrm{CC}$ & 2 & 2 & 2 & 2 & 8 & 3 & 2 & 2 & 2 & 9 \\
\hline 4. & DD & 4 & 3 & 3 & 2 & 12 & 4 & 3 & 3 & 2 & 12 \\
\hline 5. & $\mathrm{EE}$ & 2 & 2 & 3 & 2 & 9 & 3 & 2 & 3 & 3 & 11 \\
\hline 6. & FF & 3 & 3 & 2 & 2 & 10 & 3 & 3 & 4 & 3 & 13 \\
\hline 7. & GG & 4 & 3 & 2 & 2 & 11 & 4 & 3 & 3 & 3 & 13 \\
\hline 8. & $\mathrm{HH}$ & 4 & 3 & 3 & 3 & 13 & 4 & 4 & 4 & 3 & 15 \\
\hline 9. & II & 3 & 3 & 2 & 2 & 10 & 3 & 4 & 3 & 3 & 13 \\
\hline 10. & $\mathrm{JJ}$ & 2 & 2 & 2 & 2 & 8 & 2 & 3 & 2 & 3 & 10 \\
\hline 11. & KK & 2 & 2 & 3 & 2 & 9 & 3 & 3 & 3 & 3 & 12 \\
\hline
\end{tabular}

Keterangan :

AA, BB, dst : Kode nama anak

1. Tugas Satu: Menyebutkan bilangan

2. Tugas D : Mengurutkan bilangan

3. Tugas Tiga : Mencocokkan jumlah benda dan bilangan

4. Tugas Empat: Menuliskan lambang bilangan TOTAL : Jumlah nilai akhir

\section{Pembahasan}

\section{a. Pembahasan hasil analisa}

Data yang terkumpul dan dianalisis dengan tabel kerja uji $\mathrm{T}$ menghasilkan perhitungan data sebagai berikut.

Tabel: 2

Tabel Kerja Uji T hasil Pre-test dan Post-test

\begin{tabular}{|c|c|c|c|c|c|}
\hline Subjek & $\begin{array}{c}\text { Pre- } \\
\text { test }\end{array}$ & $\begin{array}{c}\text { Post- } \\
\text { Test }\end{array}$ & $\begin{array}{c}\text { Peningkatan } \\
\text { Skor }\end{array}$ & $\mathbf{X d}$ & $\mathbf{X}^{\mathbf{2} d}$ \\
\hline 1 & 10 & 12 & 2 & 0,2 & 0,04 \\
\hline 2 & 10 & 10 & - & - & - \\
\hline 3 & 8 & 9 & 1 & 0,8 & 0,64 \\
\hline 4 & 12 & 12 & - & - & - \\
\hline 5 & 9 & 11 & 2 & 0,2 & 0,04 \\
\hline 6 & 10 & 13 & 3 & 1,2 & 1,44 \\
\hline 7 & 11 & 13 & 2 & 0,2 & 0,04 \\
\hline 8 & 13 & 15 & 2 & 0,2 & 0,04 \\
\hline 9 & 10 & 13 & 3 & 1,2 & 1,44 \\
\hline 10 & 8 & 10 & 2 & 0,2 & 0,04 \\
\hline 11 & 9 & 12 & 3 & 1,2 & 1,44 \\
\hline Jumlah & $\mathbf{1 1 0}$ & $\mathbf{1 3 0}$ & $\mathbf{2 0}$ & $\mathbf{5 , 4}$ & $\mathbf{5 , 1 6}$ \\
\hline Mean & $\mathbf{1 0}$ & $\mathbf{1 1 . 8}$ & $\mathbf{1 , 8}$ & & \\
\hline
\end{tabular}

Kemudian dimasukkan ke dalam rumus uji

$\mathrm{T}$, menghasilkan nilai:

$$
\mathrm{t}=\frac{\mathrm{Md}}{\sqrt{\frac{\sum \mathrm{X}^{2} \mathrm{~d}}{\mathrm{~N}(\mathrm{~N}-1)}}}
$$

$$
\begin{array}{ll}
t=\frac{1,8}{\sqrt{\frac{5,16}{11(11-1)}}} \\
t=\frac{1,8}{\sqrt{\frac{5,16}{110}}} & t=\frac{1,8}{0,217} \quad t=
\end{array}
$$$$
8,295
$$

Berdasarkan hasil pengujian uji $t_{\text {hitung, }}$ diperoleh nilai $(8,295)$ lebih besar dari $t_{\text {tabel }}$ $(2,093)$ dengan taraf signifikasi $5 \%$. Artinya, pengenalan lambang bilangan melalui permainan menjatuhkan simbol angka untuk Anak PAUD Nurul Jadid, Tumapel No. 106/A Ketajen, Gedangan, Sidoarjo sangat efektif.

\section{b. Pembahasan secara deskriptif}

Mayoritas anak usia dini (4-5tahun) bisa mengurutkan lambang bilangan itu sifatnya hanya hafalan. Bila anak diminta untuk menunjukkan dan menyebutkan lambang bilangan, anak bisa melakukan tetapi masih harus mengurutkan dari angka satu, dua, tiga, dst. Hal ini disebabkan karena saat pelaksanaan pembelajaran mengenal bilangan guru hanya menggunakan media dari lembar kerja secara urut. Dalam pembelajaran mengenal bilangan, hanya melalui tugas yang diberikan kepada anak dengan menarik garis dari jumlah gambar menuju lambang bilangannya. Karena guru dalam memberikan tugas kepada anak kurang bervariatif, berdampak anak cepat merasa bosan, kurang bersemangat, dan tidak memudahkan anak untuk ingin mengetahui dan mendalami. Menurut Igrea Siswanto \& Lestari (2012:56 ), usia dini atau pra sekolah merupakan usia yang efektif untuk mengembangkan berbagai potensi yang dimiliki anak-anak. Proses belajar di PAUD haruslah dengan sistem bermain. Anak-anak yang kebutuhan bermainnya terpenuhi akan semakin tumbuh dengan memiliki keterampilan yang lebih tinggi, bagus, serta dapat menyesuaikan secara mudah terhadap lingkungan sekitarnya. Terkait dengan kondisi tersebut, disediakan permainan berupa permainan menjatuhkan simbol bilangan. Permainan ini ternyata sangat menarik minat anak dan membuat anak senang untuk melakukannya. Permainan ini menggunakan bahan dan media yang sederhana dan mudah didapat atau 
dibuat, yaitu menggunakan permainan bahan plastik berbentuk bowling atau bisa juga dari botol bekas air mineral $600 \mathrm{ml}$ dan satu buah bola. Sedangkan, cara bermainnya juga mudah untuk dilakukan oleh anak usia dini, yaitu bisa dengan melemparkan, menggelinding

kan, menjatuhkan bola dari arah atas permainan dengan maksud untuk menjatuhkan permainan tersebut. Adapun jarak dari arah lemparan pun juga disesuaikan dengan kemampuan anak. Hal itu dapat dilakukan dalam jarak 1, 2, 3 meter atau dengan menjatuhkan bola dari atasnya ke arah deretan botol yang disusun sejajar/memanjang. Tempat dan bentuk kegiatannya cukup memerlukan ruangan kecil dan anak duduk melingkar atau duduk berbaris memanjang. Kegiatannya adalah masing-masing anak diminta untuk melakukan sesuai perintah guru dan sesuai indikator yang telah ditetapkan dalam penelitian ini. Sesuai pendapat Susanto (2011:16), pada anak usia dini kemampuan yang akan dikembangkan diantaranya (a) mengenali atau membilang angka, (b) menyebut urutan bilangan, (c) menghitung benda, (d) menghitung himpunan dengan nilai bilangan benda, (e) menuliskan simbol angka dengan menggunakan konsep dari konkret ke abstrak. Terkait dengan pendapat tersebut, indikator dalam penelitian ini antara lain:

Indikator I adalah siswa bisa mengurutkan dan mengenal konsep bilangan $1-5$ yang diacu dari angka bilangan yang telah dijatuhkan. Ternyata, hasilnya cukup bai, dan bisa meningkat, yaitu dari 6 anak yang bisa mengurutkan angka menjadi 11 anak. Biarpun di awal pertemuan atau permainan, anak anak masih malu, dan takut untuk melakukan permainan sehingga belum sempurna ketika melempar/menggelindingkan bola. Mereka masih memerlukan arahan dan bimbingan. Setelah ada bimbingan susulan, anak senang melakukan permainan bahkan sulit untuk bergantian. Selanjutnya, dilakukan tindakan dengan menyediakan media yang sama berupa botol air mineral ukuran $600 \mathrm{ml}$, namun jumlahnya menjadi 10 buah. Semula anak hanya diminta untuk mengenal angka $1-$ 5 saja, tetapi selanjutnya anak harus mengenal angka/lambang bilangan 1 sampai dengan 10. Melalui bermain menjatuhkan lambang bilangan $1-10$, anak bisa mencapai indikator II yakni anak bisa mengurutkan bilangan yang dijatuhkan dari angka kecil ke besar atau sebaliknya. Misalnya, bila anak menjatuhkan angka $2,4,8,5,1,9$, dan 3 kemudian anak diminta untuk mengurutkan angka-angka tersebut dari urutan besar ke urutan kecil, mereka sudah bisa. Anak sudah bisa menyusunnya dengan bentuk $9,8,5,4$, 3, 2, dan 1. Disamping itu juga, bisa mencapai indikator III (mencocokkan antara jumlah benda dengan simbol angkanya. Misalnya, anak ditunjukkan gambar pensil sebanyak 7. Setelah itu, anak diminta untuk memilih dan menjatuhkan angka tersebut. Bila anak bisa melakukan dengan tepat, berarti anak sudah bisa mencocokkan antara simbol angka dengan jumlah benda yang ada. Sedangkan, indikator IV (menulis simbol angka), pada umumnya anak sudah bisa menirukan bahkan menulisnya sendiri. Bila anak disuruh gurunya untuk menuliskan angka tertentu, anak sudah bisa melakukannya dengan tepat atau betul. Akan tetapi, sampai akhir penelitian masih ada dua anak yang belum maksimal untuk mencapai 4 indikator tersebut, karena 2 anak tersebut sering tidak masuk sekolah karena sakit. Mereka hanya mampu menyebut dan mengurutkan sebagian lambang bilangan, dan belum mengerti konsep bilangan 1-10 secara utuh. Disamping itu, bila disuruh untuk menuliskan sebuah angka, mereka kadangkadang bisa dengan tepat, dan kadang-kadang masih salah atau tidak tepat.

Dengan demikian, artikel ini menunjukkan bahwa permainan menjatuhkan simbol angka dapat bermanfaat untuk mengenalkan lambang bilangan dan mengatasi permasalahan yang sering muncul dalam pembelajaran mengenal angka bagi anak usia dini. Adapun bentuk dan hasil kemanfaatannya antara lain:

(a) Anak yang semula menyebut bilangan secara hafalan, sekarang sudah bisa menyebut dengan memahami konsep bilangan.

(b) Anak yang semula bisa mengurutkan lambang bilangan dari kecil ke besar, sekarang mereka sudah bisa mengurutkan secara terbalik, dari besar ke kecil.

(c) Anak yang semula bisa mencocokkan jumlah benda dengan simbol angka 
dengan bantuan guru, sekarang sudah tidak lagi dibantu guru.

(d) Anak semula tidak bisa menuliskan simbol angka 1-10, sekarang mayoritas sudah bisa menulis simbol angka dengan benar dan cukup jelas.

\section{KESIMPULAN}

Berdasarkan hasil penelitian dan pembahasan, dapat diambil kesimpulan sebagai berikut:

a) Pembelajaran melalui bermain sangat efektif digunakan sebagai wahana dalam mengenalkan lambang bilangan untuk anak usia dini

b) Permainan menjatuhkan lambang bilangan atau sesuatu, baik dengan bentuk melempar, menggelin dingkan, menjatuhi, maupun menendang dengan kaki, sangat tepat diberikan kepada anak usia dini. Sebab, permainan ini sangat mudah dilakukan dan mengasyikkan pada anak usia dini.

c) Permainan yang mengasyikkan dapat digunakan untuk penyelesaian masalahnya anak usia dini, khususnya dalam pengenalan lambang bilangan.

\section{REFERENSI}

Direktorat Pembinaan Taman Kanak-kanak dan Sekolah Dasar,(2008). Pengembangan Model Pembelajaran di Tman Kanak Kanak. Departemen Pendidikan Nasional, Direktorat Jenderal Menengah Pendidikan Dasar dan Menengah, Jakarta, Direktorat Pembinaan TK dan SD.

Docket, S dan Fleer, M. (1999). Play and Pedagogy. Sydney: Harcourt.

Goldstein, Jefferi H. (Editor). (1994) Toys, Play and Children Develop ment. New York: Cambridge University Press.

Jamaris, Martini. (2006). Perkemban gan dan Pengembangan Anak Usia Taman Kanakkanak. Jakarta: Grasindo.

Kuffner, Trish. (2004). Play and Learn: 300 Aktivitas Bermain dan Belajar Bersama Anak (Usia 3-6 Tahun). (terj.), Jakarta: Elek Media Komputindo.

Meyke S. Tedjasaputra, (2001). Bermain, Mainan, dan Permainan. Jakarta: Grasindo.

Moeslichatoen. (2004). Metode Pengajaran di Taman Kanak-kanak.. Jakarta: PT. Rineka Cipta,
Samsudin. (2008). Pembelajaran Motorik di Taman Kanak-kanak. Jakarta, Litera Prenada Media Group.

Seefeldt, Carol and Barbara A. Wasik. (2008). Pendidikan Anak Usia Dini: Menyiapkan Anak Usia Tiga, Empat, dan Lima Tahun Masuk Sekolah. Jakarta: Indeks.

Siswanto, Igrea \& Lestari, Sri.(2012). Pembelajaran Atraktif dan 100 Permainan Kreatif. Yogyakarta: ANDI Yogyakarta.

Stupiansky, Sandra Waite. (1992). Learning Through Play Math: Practical Guide for Teaching Young Children. New York: Scolastic.

Sudono, Anggani. (2010). Sumber Belajar dan Alat Permainan untuk Pendidikan Anak Usia Din. Jakarta: PT Grasindo. -, (2007). Permainan Kreatif. Jakarta, PM. Pustaka.

Sujiono, Y. N., dan Bambang S. (2010). Bermain Kreatif Berbasis Kecerdasan Jamak. Jakarta: Indeks.

Toho Cholik Mutohir. (2004). Perkembangan Motorik Pada Masa Anak-Anak. Proyek Pengembangan dan Keserasian, Kebijakan Olahraga, Jakarta, Departemen Pendidikan Nasional.

http://dewinthaocean.multiply.com/photos/album /118/Bermain-Adalah-Pekerjaan-UtamaAnak, diakses 6 Agustus 2014.

http://id.88db.com/OlahragaF itness/PermainanBola/ad-88983/, diakses 6 Agustus 2014. http://id.wikipedia.org/wiki/Bowling. diakses 6 Agustus 2014. 